ARTICLE

\title{
East Siberian Arctic inland waters emit mostly contemporary carbon
}

Joshua F. Dean (1,2凶, Ove H. Meisel', Melanie Martyn Rosco', Luca Belelli Marchesini (10 3,4, Mark H. Garnett (10) ${ }^{5}$, Henk Lenderink', Richard van Logtestijn (1) ${ }^{6}$, Alberto V. Borges ${ }^{7}$, Steven Bouillon (1) ${ }^{8}$, Thibault Lambert ${ }^{7}$, Thomas Röckmann (1) ${ }^{9}$, Trofim Maximov ${ }^{10,11}$, Roman Petrov (i) ${ }^{10,11}$, Sergei Karsanaev ${ }^{10,11}$, Rien Aerts ${ }^{6}$, Jacobus van Huissteden ${ }^{1}$, Jorien E. Vonk ${ }^{1} \&$ A. Johannes Dolman (D) ${ }^{1}$

Inland waters (rivers, lakes and ponds) are important conduits for the emission of terrestrial carbon in Arctic permafrost landscapes. These emissions are driven by turnover of contemporary terrestrial carbon and additional pre-aged (Holocene and late-Pleistocene) carbon released from thawing permafrost soils, but the magnitude of these source contributions to total inland water carbon fluxes remains unknown. Here we present unique simultaneous radiocarbon age measurements of inland water $\mathrm{CO}_{2}, \mathrm{CH}_{4}$ and dissolved and particulate organic carbon in northeast Siberia during summer. We show that $>80 \%$ of total inland water carbon was contemporary in age, but pre-aged carbon contributed $>50 \%$ at sites strongly affected by permafrost thaw. $\mathrm{CO}_{2}$ and $\mathrm{CH}_{4}$ were younger than dissolved and particulate organic carbon, suggesting emissions were primarily fuelled by contemporary carbon decomposition. Our findings reveal that inland water carbon emissions from permafrost landscapes may be more sensitive to changes in contemporary carbon turnover than the release of pre-aged carbon from thawing permafrost.

\footnotetext{
${ }^{1}$ Department of Earth Sciences, Vrije Universiteit Amsterdam, Amsterdam, the Netherlands. ${ }^{2}$ School of Environmental Sciences, University of Liverpool, Liverpool, UK. ${ }^{3}$ Department of Sustainable Agro-ecosystems and Bioresources, Research and Innovation Centre, Fondazione Edmund Mach, San Michele all'Adige, Italy. ${ }^{4}$ Department of Landscape Design and Sustainable Ecosystems, Agrarian-Technological Institute, RUDN University, Moscow, Russia.

${ }^{5}$ Natural Environment Research Council Radiocarbon Facility, East Kilbride, UK. ${ }^{6}$ Department of Ecological Sciences, Vrije Universiteit Amsterdam, Amsterdam, the Netherlands. ${ }^{7}$ Chemical Oceanography Unit, University of Liège, Liège, Belgium. ${ }^{8}$ Department of Earth and Environmental Science, Katholieke Universiteit Leuven, Leuven, Belgium. ${ }^{9}$ Institute for Marine and Atmospheric Research, Utrecht University, Utrecht, the Netherlands. ${ }^{10}$ Institute for Biological Problems of the Cryolithozone, Siberian Branch Russian Academy of Sciences, Yakutsk, Russia. ${ }^{11}$ North-Eastern Federal University,

Yakutsk, Russia. ${ }^{凶}$ email: joshua.dean@liverpool.ac.uk
} 
nland waters are highly abundant and important pathways for the export of terrestrial carbon (C) in northern high-latitude permafrost landscapes where $\sim 50 \%(\sim 1300 \mathrm{Pg} \mathrm{C})$ of the global soil organic $\mathrm{C}$ pool is stored ${ }^{1,2}$. This $\mathrm{C}$ is increasingly vulnerable to destabilization and release due to permafrost thaw driven by rising Arctic air temperatures ${ }^{2-4}$. Inland waters in stable permafrost landscapes primarily receive terrestrial $C$ from contemporary biological turnover within seasonally thawed topsoils ${ }^{5-7}$. As these landscapes warm, it is likely more contemporary $\mathrm{C}$ will be released to inland waters from sustained and enhanced biological turnover and event-based vegetation die-off (Arctic greening versus browning $)^{8,9}$. As permafrost soils thaw, additional old C that had remained frozen since the Holocene is also released to inland waters ${ }^{7}$. Twenty-five percent of permafrost soil $\mathrm{C}$ is located in regions with substantial deposits of even older, ancient Pleistocene-aged sediments called Yedoma that is particularly vulnerable to thaw due to its high ice content, the majority of which is located in northeast Siberia ${ }^{1}$. These contemporary terrestrial $\mathrm{C}$ and old and ancient (pre-aged) $\mathrm{C}$ sources are released to inland waters in four main forms: dissolved and particulate organic $\mathrm{C}(\mathrm{DOC}<0.2-0.7 \mu \mathrm{m}$ in size $<\mathrm{POC})$, dissolved inorganic $\mathrm{C}$ (including $\mathrm{CO}_{2}$ ), and $\mathrm{CH}_{4}$ (ref. ${ }^{2}$ ). Shifts in the ratio of these $\mathrm{C}$ forms from one to another, or increases in total inland water $\mathrm{C}$ concentrations, can drive the magnitude of potential climate feedbacks $2,10,11$.

Terrestrial $\mathrm{C}$ can be readily decomposed to $\mathrm{CO}_{2}$ and $\mathrm{CH}_{4}$ during transport and storage in inland waters and this is thought to be an important driver of permafrost landscape $\mathrm{C}$ emissions. Radiocarbon $\left({ }^{14} \mathrm{C}\right)$ based studies in Yedoma regions have shown that pre-aged $\mathrm{C}$ is highly vulnerable to microbial decomposition to $\mathrm{CO}_{2}$ when released into streams ${ }^{12-14}$, while studies targeting thermokarst lakes (formed from abrupt thaw processes) detected $\mathrm{CH}_{4}$ emissions as old as 42,900 years before present $(\mathrm{yBP})^{15}$. In contrast, contemporary $\mathrm{C}$ dominated emissions to the atmosphere in non-Yedoma permafrost regions ${ }^{6,7,16,17}$, and ice-core studies suggest it is unlikely that large-scale emissions of pre-aged $\mathrm{CH}_{4}$ from permafrost regions have occurred in the past $\sim 15,000$ years ${ }^{18}$. It therefore remains unclear whether the release of preaged permafrost $\mathrm{C}$ into inland waters is an important driver of landscape-scale $\mathrm{C}$ emissions relative to contemporary $\mathrm{C}$ turnover.

Here we quantify the contributions of pre-aged and contemporary $\mathrm{C}$ in all forms to inland waters of a lowland permafrost landscape. Using an isotope mixing model, we determine the age of $\mathrm{C}$ contributions to inland water emissions from simultaneous ${ }^{14} \mathrm{C}$ and concentration measurements of DOC, POC, and dissolved $\mathrm{CO}_{2}$ and $\mathrm{CH}_{4}$ across a selection of inland water sites in the continuous permafrost zone of the northeast Siberian tundra (Fig. 1). We focus on dissolved $\mathrm{CO}_{2}$ and $\mathrm{CH}_{4}$ rather than ebullition (bubble release) because the dissolved gases provide a more spatiotemporally integrated measure of high-latitude inland water greenhouse gas release ${ }^{19}$. The selected sites cover shallow tundra ponds ( $<0.5 \mathrm{~m}$ deep, $3-240 \mathrm{~m}^{2}$ in area) with very limited access to pre-aged C (sites P01-12), fluvial systems consisting of an irregularly connected pond and a $\sim 5 \mathrm{~m}$ wide stream draining a drained lake basin (sites S01-04), two small lakes ( $<3 \mathrm{~m}$ deep, 0.04 and $0.14 \mathrm{~km}^{2}$ ) in thaw-depression and drained lake basin dominated tundra (sites L06-12), and a thermokarst lake (up to 7 $\mathrm{m}$ depth, $0.51 \mathrm{~km}^{2}$; sites L01-05) that is eroding into a Yedoma ridge (Fig. 1; Table 1 and Supplementary Table 1). ${ }^{14} \mathrm{C}$ samples were also collected from meltwater draining directly from a thawing Yedoma ice mass in the eroding bank of the thermokarst lake (adjacent to site L01 in Fig. 1) to assess the maximum potential age of $\mathrm{C}$ mobilized into solution during Yedoma thaw. We expected contemporary $\mathrm{C}$ to dominate in the pond, fluvial and small shallow lake sites where inputs of pre-aged $\mathrm{C}$ are limited, and pre-aged $\mathrm{C}$ to dominate in both the thermokarst lake, which actively erodes into Yedoma sediments, and the Yedoma meltwater. We aimed to capture a snapshot of the likely oldest $\mathrm{C}$ released during the growing season by collecting samples in July-August 2016 when the seasonally thawed active layer was deepest and thermokarst erosion was at its maximum (Supplementary Fig. 1) $)^{7,20}$. However, it is worth noting that the oldest $\mathrm{C}$ emitted to the atmosphere by such inland waters may occur at the end of winter due to the buildup of $\mathrm{CO}_{2}$ and $\mathrm{CH}_{4}$ under ice, which also isolates inland waters from contemporary inputs ${ }^{19}$. Inland water $\mathrm{C}$ emissions were upscaled for the $15.9 \mathrm{~km}^{2}$ study region (Fig. 1), and the relative contributions of pre-aged and contemporary $\mathrm{C}$ were estimated and contextualized with tundra emissions measured using eddy covariance. The study region is representative of wider northeast Siberian Arctic landscapes, which are dominated by ponds, fluvial networks, drained thaw lake basins and remnant Yedoma deposits ${ }^{21-23}$.

\section{Results}

Inland water carbon isotope compositions. The ${ }^{14} \mathrm{C}$ ages across the different sampling locations revealed an age gradient ranging from modern (post-1950 CE) to ancient $(29,355 \pm 2967 \mathrm{yBP}$; mean $\pm 1 \sigma$; Fig. $2 \mathrm{a})$ : pond sites were the youngest, followed by increasing ${ }^{14} \mathrm{C}$ ages in the fluvial, small lake, thermokarst lake and Yedoma meltwater sites (Fig. 2b). Pond, fluvial and small lake ${ }^{14} \mathrm{C}$ ages were statistically alike, ranging from $1679 \pm 38 \mathrm{yBP}$ to modern; thermokarst lake and Yedoma meltwater ${ }^{14} \mathrm{C}$ ages were significantly older $(29,355 \pm 2967$ to $1234 \pm 38$ yBP; Fig. $2 b)$.

${ }^{14} \mathrm{CO}_{2}$ values were consistently younger than the other ${ }^{14} \mathrm{C}$ forms and ${ }^{14} \mathrm{CH}_{4}$ was generally younger than $\mathrm{PO}^{14} \mathrm{C}$, based on linear regressions testing for age divergence between the different ${ }^{14} \mathrm{C}$ forms. These regressions were sensitive to extreme values due to limited sample numbers, so thermokarst lake and Yedoma ${ }^{14} \mathrm{C}$ values were excluded initially. All ${ }^{14} \mathrm{C}$ forms were significantly correlated with one another $\left(p<0.05 ; R^{2}=0.54-0.94\right.$; Supplementary Fig. 2). Including the thermokarst and Yedoma samples increased the level of correlation $\left(p<0.001 ; R^{2}=0.74-0.98\right.$; Supplementary Fig. 3), but $\mathrm{CO}_{2}$ and $\mathrm{CH}_{4}$ were still younger than DOC and POC (except thermokarst lake $\mathrm{CH}_{4}$ and POC, which were approximately the same; Fig. 2a).

The $\delta^{13} \mathrm{C}-\mathrm{CO}_{2}$ values reflect mixing of respiration of recent and decomposed organic matter with some contribution from methanogenesis as well ${ }^{24,25}$. The less negative $\delta^{13} \mathrm{C}-\mathrm{CO}_{2}$ values $(-22.9$ to $-12.1 \%$ ) in comparison with $\mathrm{CH}_{4}$ were consistent with $\mathrm{CO}_{2}$ samples collected from Canadian Arctic inland waters ${ }^{7}$. The least negative $\delta^{13} \mathrm{C}-\mathrm{CO}_{2}$ values indicated there could be some exchange with atmospheric $\mathrm{CO}_{2}$ which has a less negative $\delta^{13} \mathrm{C}$ value $(-9 \%)$ than respired organic matter $(-30.0 \text { to }-16.2 \%)^{19,22,26}$, but all sites were supersaturated with $\mathrm{CO}_{2}$ compared with the atmosphere, limiting ingress of atmospheric $\mathrm{CO}_{2}$ into the water. The $\delta^{13} \mathrm{C}-\mathrm{CH}_{4}$ values indicated production from microbial methanogenesis $(-63.8$ to $-46.7 \%$ ), although the least negative value was close to thermogenic $\mathrm{CH}_{4}(-45 \text { to }-20 \%)^{24}$ but this could also reflect enrichment by partial methane oxidation ${ }^{19,24}$. The isotopic separation factor $\left(\varepsilon_{\mathrm{C}}\right)$ of $\delta^{13} \mathrm{C}-\mathrm{CO}_{2}$ and $\delta^{13} \mathrm{C}-\mathrm{CH}_{4}$ $\left(\approx \delta^{13} \mathrm{C}-\mathrm{CO}_{2}-\delta^{13} \mathrm{C}-\mathrm{CH}_{4}\right)$ can indicate the pathway of $\mathrm{CH}_{4}$ production. The $\varepsilon_{\mathrm{C}}$ values in this study were 32.7-45.6 (42.1 \pm 4.8 [median $\pm 1 \sigma$ ]; Supplementary Data 1 ), which indicates $\mathrm{CH}_{4}$ formation from bacterial methyl-type fermentation (decomposition of methylated organic matter compounds; Fig. 2a) as opposed to the reduction of carbonate, thermogenic sources, or exchange with the atmosphere ${ }^{24}$. Geological contributions to $\mathrm{CO}_{2}$ or $\mathrm{CH}_{4}$ isotopic signatures are very unlikely at the study site (see Methods). The $\delta^{13} \mathrm{C}-\mathrm{DOC}$ values $(-29.9$ to $-26.2 \%$ ) were consistent with freshwater DOC derived from the C3 photosynthetic pathway ${ }^{7,25,27} ; \delta^{13} \mathrm{C}$-POC values were more negative 


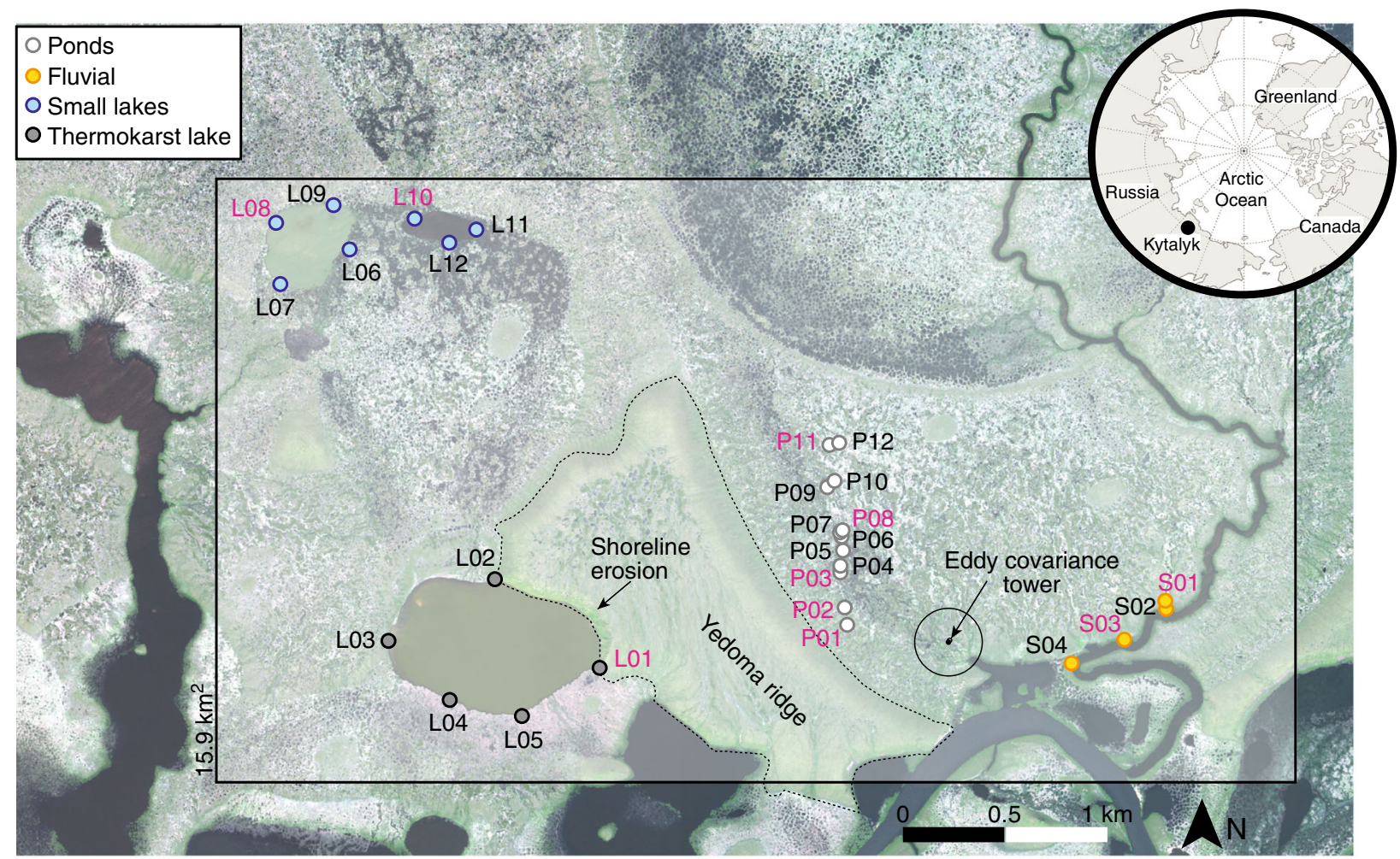

Fig. 1 Study region and sampling locations. Sampling locations for concentrations (black text) and radiocarbon (magenta text), eddy covariance tower (black dot) and its footprint (black circle represents $75-90 \%$ of flux contributions ${ }^{44}$ ), Yedoma ridge (dashed black outline), and location of the site within the Arctic (inset). The box $\left(15.9 \mathrm{~km}^{2}\right.$ ) indicates the area used for upscaled fluxes (Table 1). Background is a panchromatic Worldview satellite image from 15 July 2015, WorldView (c) 2019 MAXAR.

$(-33.7$ to $30.6 \%$ ), reflecting the presence of vegetation fragments $^{25}$ (Fig. 2a).

Contemporary versus pre-aged carbon sources. A five-source isotope mass balance model $6,28,29$ was used to estimate relative contributions to the measured ${ }^{14} \mathrm{C}$ values from $\mathrm{C}$ sources measured at the study site ${ }^{22}$. These $C$ sources were defined as contemporary (modern atmospheric $\mathrm{C}$, topsoil and late-Holocene basal peat: $2013 \mathrm{CE}$ to $1180 \mathrm{yBP}$ ) and pre-aged C (old Holocene C and ancient Yedoma C: $1765 \mathrm{yBP}$ to $>27,920 \mathrm{yBP}$ ) (Fig. 2a; see Methods). The majority of inland water $\mathrm{C}$ observed in this study was contemporary, but pre-aged $\mathrm{C}$ contributed to all inland water $\mathrm{C}$ forms where permafrost thaw occurred (Fig. 2a). Pond, fluvial and small lake $\mathrm{C}$ was primarily derived from modern and topsoil C sources $(>56 \% \pm 33 \%$ [mean $\pm \sigma]$; Fig. 3; Supplementary Table 2). When basal peat sources were included, these three contemporary sources accounted for $>83_{-53}^{+17} \%$ of the $\mathrm{C}$ in these waters (Table 1). In the thermokarst lake and Yedoma meltwater, the majority of $\mathrm{C}$ was pre-aged $(>50 \% \pm 35 \%)$ (Fig. 3 ; Table 1$)$.

Carbon concentrations. DOC had the highest concentrations of the four $\mathrm{C}$ forms measured $\left(15.8 \pm 12.3 \mathrm{mg} \mathrm{C} \mathrm{L}^{-1}\right.$ [mean $\left.\pm 1 \sigma\right]$; Fig. 4; Supplementary Fig. 4). POC and $\mathrm{CO}_{2}$ concentrations were statistically alike $\left(2.6 \pm 3.0 \mathrm{mg} \mathrm{C} \mathrm{L}^{-1}\right.$ versus $\left.2.8 \pm 3.2 \mathrm{mg} \mathrm{C} \mathrm{L}^{-1}\right)$, lower than DOC but higher than $\mathrm{CH}_{4}\left(0.1 \pm 0.3 \mathrm{mg} \mathrm{C} \mathrm{L}^{-1}\right)$. Pond $\mathrm{C}$ concentrations were consistently higher than fluvial, small lake or thermokarst lake sites, with the latter three containing statistically alike concentrations (Fig. 4). Yedoma meltwater had the highest organic $\mathrm{C}$ concentrations $\left(\mathrm{DOC}=42.5 \mathrm{mg} \mathrm{C} \mathrm{L}^{-1}\right.$, $\mathrm{POC}=8.5 \mathrm{mg} \mathrm{CL}^{-1}$; Table 1). Sites with higher $\mathrm{CO}_{2}$ concentrations had younger ${ }^{14} \mathrm{CO}_{2}$ ages $\left(p<0.05, R^{2}=0.71\right.$; the best fit was exponential; Fig. $4 c$ ). While this was the only statistically significant relationship, waters with higher overall C concentrations tended to be younger (Fig. 4).

Dissolved organic matter characteristics. We used absorbance and fluorescence spectroscopy to determine the source and decomposition pathways of inland water dissolved organic matter (DOM) which includes DOC, the C form with the highest concentrations. DOM can be produced by terrestrial and microbial production or decomposed by microbial degradation and photooxidation $^{30}$

The DOM was primarily derived from terrestrial material, and both microbial activity and photo-oxidation played a role in its decomposition. Relatively high humic content (Humification Index $[\mathrm{HIX}]$ values $=0.6-0.7)$, indicates a predominantly terrestrial origin, as do substantial contributions of parallel factor analysis (PARAFAC) components $\mathrm{C} 1, \mathrm{C} 3$, and $\mathrm{C} 4$ to the total DOM fluorescence signal, which are associated with high aromaticity and intermediate/high-molecular weight terrestrial DOM (Supplementary Fig. 5). Higher microbial contributions to the DOM pool were associated with older DOC, indicated by increasing biological index (BIX) values and decreasing humic content with older ages (Supplementary Fig. 6). This suggests increased microbial activity that could include the decomposition of organic $\mathrm{C}$ to $\mathrm{CO}_{2}$ and $\mathrm{CH}_{4}$, and/or the incorporation of organic $\mathrm{C}$ into microbial biomass. Photo-oxidation likely contributed to the decomposition of younger DOM which had higher molecular weight and aromaticity-characteristic of photosensitive molecules ${ }^{31}$-than older DOM. This trend in molecular weight is shown by an increase in $S_{R}$ (slope ratio) and $\mathrm{E}_{2}: \mathrm{E}_{3}$ ratio with older ages, both inversely proportional to molecular weight, alongside a decrease in percent $\mathrm{C} 1$ (proportional contribution of PARAFAC component $\mathrm{C} 1$ to the total 


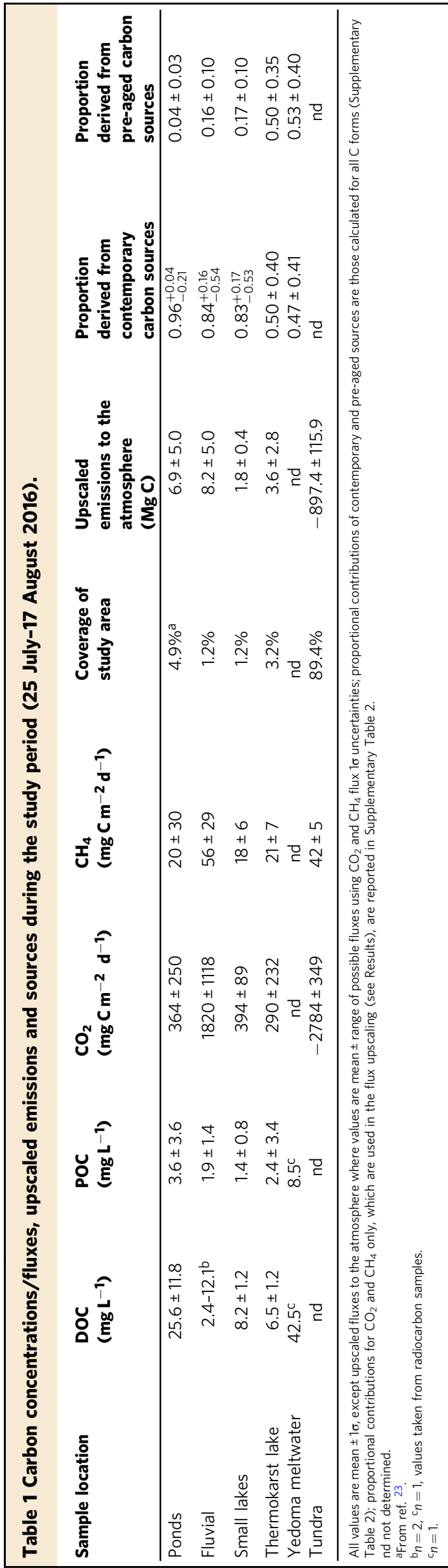

fluorescence signal) which is associated with high aromaticity and high-molecular weight terrestrial DOM (Supplementary Fig. 6).

Landscape-scale carbon emissions. The study region was a $\mathrm{C}$ sink with a net flux of $-876.9 \pm 136.4 \mathrm{Mg} \mathrm{C}$ during the study period, 25 July-17 August 2016 (summing the upscaled fluxes to the atmosphere in Table 1). This was mainly due to the tundra surrounding the inland waters which was a $\mathrm{CO}_{2}$ sink $(-2784 \pm$ $349 \mathrm{mg} \mathrm{C}-\mathrm{CO}_{2} \mathrm{~m}^{-2} \mathrm{~d}^{-1}$ ) partially offset by tundra $\mathrm{CH}_{4}$ emissions ( $43 \pm 5 \mathrm{mg} \mathrm{C}-\mathrm{CH}_{4} \mathrm{~m}^{-2} \mathrm{~d}^{-1}$; Table 1$) .89 .4 \%$ of the landscape was tundra $\left(14.2 \mathrm{~km}^{2}\right.$; Fig. 1$)$, and thus dominated total $\mathrm{C}$ flux per unit area and by spatial extent. Of the inland waters, fluvial sites had the highest $\mathrm{CO}_{2}$ emissions $(1820 \pm 1118 \mathrm{mg}$ $\mathrm{C}-\mathrm{CO}_{2} \mathrm{~m}^{-2} \mathrm{~d}^{-1}$ [mean $\left.\pm 1 \sigma\right]$; Table 1; Supplementary Fig. 7). Emissions from the pond, small lake and thermokarst lake were all lower than fluvial emissions but not significantly different from one another $\left(290 \pm 232\right.$ to $\left.394 \pm 89 \mathrm{mg} \mathrm{C}--\mathrm{CO}_{2} \mathrm{~m}^{-2} \mathrm{~d}^{-1}\right)$. The same pattern was evident for $\mathrm{CH}_{4}$ : fluvial diffusive emissions were $56 \pm 29 \mathrm{mg} \mathrm{C}-\mathrm{CH}_{4} \mathrm{~m}^{-2} \mathrm{~d}^{-1}$, compared with $18 \pm 6$ to $20 \pm$ $30 \mathrm{mg} \mathrm{C}-\mathrm{CH}_{4} \mathrm{~m}^{-2} \mathrm{~d}^{-1}$ from the other sites (Supplementary Fig. 7). $\mathrm{CO}_{2}$ and $\mathrm{CH}_{4}$ emissions from the fluvial, small lake, and pond fluxes $\left(1.45 \mathrm{~km}^{2}, 7.3 \%\right.$ of the study region) were $16.8 \pm 10.4$ $\mathrm{Mg} \mathrm{C}$; the thermokarst lake emissions $\left(0.51 \mathrm{~km}^{2}, 3.2 \%\right.$ of the study region) were $3.6 \pm 2.8 \mathrm{Mg} \mathrm{C}$. Of these fluxes, contemporary $\mathrm{C}$ emissions were $17.0 \pm 10.9 \mathrm{Mg} \mathrm{C}$ and pre-aged $\mathrm{C}$ emissions were $3.5 \pm 2.3 \mathrm{Mg} \mathrm{C}$, offsetting $1.9 \pm 1.2 \%$ and $0.4 \pm 0.3 \%$ of the tundra sink, respectively.

\section{Discussion}

We demonstrate that the inland waters in this permafrost landscape were primarily fueled by contemporary C. We also present direct evidence that pre-aged $\mathrm{C}$ can be simultaneously released in all four main inland water $\mathrm{C}$ forms where permafrost thaw is occurring. $\mathrm{CO}_{2}$ and $\mathrm{CH}_{4}$ tended to be younger than $\mathrm{DOC}$ and POC, indicating that contemporary $\mathrm{C}$ fuels summer inland water emissions in the study region. This is due to the relatively high abundance of contemporary organic $\mathrm{C}$ relative to pre-aged $\mathrm{C}$, and contemporary DOC being more readily photo-oxidized than preaged $\mathrm{C}$. The flipside of this finding is that pre-aged inland water $\mathrm{C}$ emissions described in previous studies may be caused by the absence of contemporary $\mathrm{C}$ as much as by the vulnerability of pre-aged $\mathrm{C}$ to microbial decomposition. Given the predominance of labile contemporary $\mathrm{C}$ in the inland waters observed in this study, these systems show a high connectivity with contemporary terrestrial $\mathrm{C}$, and are thus likely more sensitive to shifts in contemporary $\mathrm{C}$ cycling than the cycling of thawed pre-aged $\mathrm{C}$.

Evidence for contemporary $\mathrm{C}$ fueling inland waters in this permafrost landscape is demonstrated by the pond, fluvial and small lake sites having the largest upscaled inland water $\mathrm{C}$ emissions (equivalent to $2.3 \pm 1.5 \%$ of the tundra $\mathrm{C}$ sink), of which $>80 \%$ was contemporary $\mathrm{C}$ (Table 1 ). In general, sites with higher $\mathrm{C}$ concentrations tended to be younger (Fig. 4). However, the high proportion of pre-aged $\mathrm{C}$ contributing to the thermokarst lake and Yedoma meltwater demonstrates that permafrost thaw will release old and ancient $\mathrm{C}$ to all inland water $\mathrm{C}$ forms. Across this gradient of inland water ${ }^{14} \mathrm{C}$ ages (Fig. $2 \mathrm{~b}$ ), the generally close relationship of $\mathrm{CH}_{4}$ with DOC and POC with DOC suggests that $\mathrm{C}$ release across these different forms was consistently from similar sources. The divergent relationship between $\mathrm{DO}^{14} \mathrm{C} / \mathrm{PO}^{14} \mathrm{C}$ and ${ }^{14} \mathrm{CO}_{2}$, and $\mathrm{PO}^{14} \mathrm{C}$ and ${ }^{14} \mathrm{CH}_{4}$ was driven by the younger age of the gaseous $\mathrm{C}$ (Fig. 2a). This implies that the $\mathrm{C}$ fueling inland water $\mathrm{CO}_{2}$ and $\mathrm{CH}_{4}$ emissions was generally younger than mobilized DOC and $\mathrm{POC}^{7,32}$, and that the most labile organic matter pools were also the youngest. 

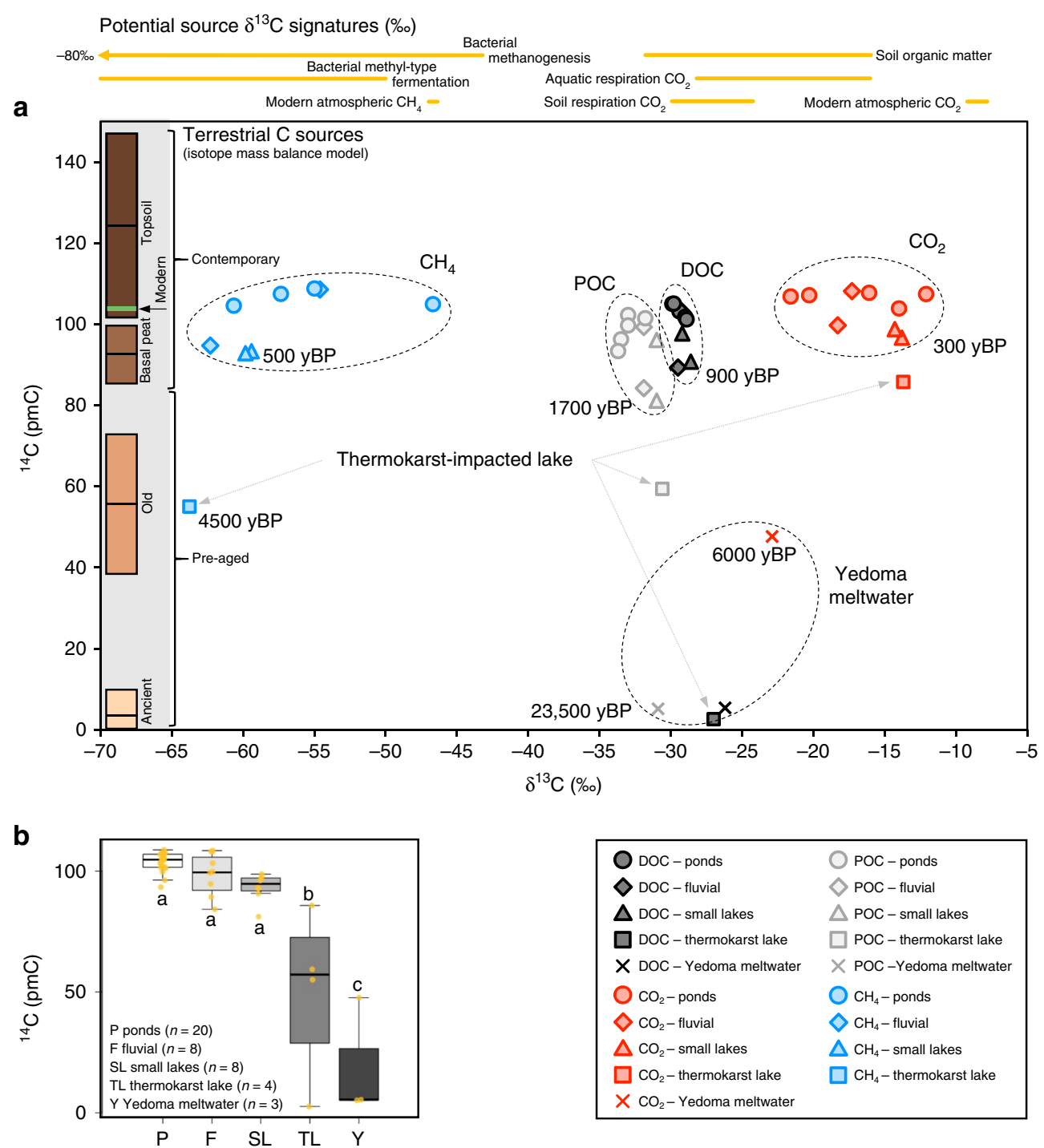

\begin{tabular}{|c|c|}
\hline DOC - ponds & POC-ponds \\
\hline$\checkmark \mathrm{DOC}$ - fluvial & $>$ POC - fluvial \\
\hline$\Delta \mathrm{DOC}$-small lakes & $\triangle P O C$ - small lakes \\
\hline$\square \mathrm{DOC}$ - thermokarst lake & $\square$ POC - thermokarst lake \\
\hline X DOC - Yedoma meltwater & $\times$ POC - Yedoma meltwater \\
\hline $\mathrm{O} \mathrm{CO}_{2}$ - ponds & $\mathrm{O} \mathrm{CH}_{4}-$ ponds \\
\hline$\checkmark \mathrm{CO}_{2}-$ fluvial & $\triangle \mathrm{CH}_{4}-$ fluvial \\
\hline$\Delta \mathrm{CO}_{2}-$ small lakes & $\Delta \mathrm{CH}_{4}-$ small lakes \\
\hline $\begin{array}{l}\square \mathrm{CO}_{2} \text { - thermokarst lake } \\
\times \mathrm{CO}_{2}-\text { Yedoma meltwater }\end{array}$ & $\square \mathrm{CH}_{4}$ - thermokarst lake \\
\hline
\end{tabular}

Fig. 2 Isotope ( ${ }^{14} \mathbf{C}$ and $\delta^{13} \mathbf{C}$ ) composition of all carbon forms. a Dissolved organic carbon (DOC), particulate organic carbon (POC), and dissolved carbon dioxide $\left(\mathrm{CO}_{2}\right)$ and methane $\left(\mathrm{CH}_{4}\right)$ across all sample locations; the bars on the left indicate the ${ }^{14} \mathrm{C}\left(\right.$ not $\left.\delta^{13} \mathrm{C}\right)$ values (mean $\left.\pm 1 \sigma\right)$ of the five sources used in the isotope mass balance; ${ }^{14} \mathrm{C}$ ages are indicative (years before present; yBP); $\delta^{13} \mathrm{C}$ signatures of potential carbon sources are indicated at the top: modern atmospheric $\mathrm{CH}_{4}$ (ref. ${ }^{45}$ ), bacterial methanogensis and bacterial methyl-type fermentation ${ }^{24}$, aquatic (permafrost freshwaters) respiration $\mathrm{CO}_{2}$ (refs. ${ }^{19,26}$ ), soil respiration $\mathrm{CO}_{2}$ and soil organic matter from the study site (including Yedoma soils) ${ }^{22}$, and modern atmospheric $\mathrm{CO}_{2}\left(\right.$ ref. ${ }^{25}$ ). b ${ }^{14} \mathrm{C}$ signatures across all carbon forms by sample location; the thick horizontal lines represent the median, limits of the boxes represent upper and lower quartiles, whiskers extend to 1.5 times the interquartile range, dots represent all data points, letters indicate statistical differences between the sample locations using ANOVA (see Methods).

Permafrost thaw can result in high concentrations of low molecular weight DOC and high POC concentrations being released to inland waters ${ }^{2,12}$. Incubation-based ${ }^{14} \mathrm{C}$ studies have suggested that this pre-aged $\mathrm{C}$ may be rapidly decomposed to $\mathrm{CO}_{2}$ (refs. ${ }^{12-14}$ ). Our simultaneous in situ ${ }^{14} \mathrm{CO}_{2}$ and ${ }^{14} \mathrm{CH}_{4}$ observations were generally younger than DOC and POC suggesting that contemporary $\mathrm{C}$ is also being rapidly decomposed in thaw affected inland waters, potentially at a faster rate or in greater proportion than pre-aged C. The utilization of pre-aged C by microbes previously demonstrated in streams draining thawing ancient Yedoma sediments ${ }^{12-14}$ could therefore just be due to the limited availability of contemporary organic $\mathrm{C}$ in those systems. This effect is amplified by these studies targeting streams heavily impacted by thermokarst activity, and the incubation approaches used which restrict contemporary inputs entirely. Our findings show that the large amount and high lability of contemporary $\mathrm{C}$ mean that it can dominate $\mathrm{C}$ cycling compared with thawed pre-aged $\mathrm{C}$ in permafrost systems at the landscapescale.

The majority of terrestrial $\mathrm{C}$ released into the study inland waters was in the form of DOC (Fig. 4) 33 . Our DOM spectroscopy results indicated that the decomposition pathways for DOC was dependent on its source: younger DOC was more vulnerable to photo-oxidation whilst older DOC was more vulnerable to microbial decomposition. Pre-aged permafrost DOC is known to be readily decomposed by microbes ${ }^{12-14}$, and this is supported by the older $\mathrm{CO}_{2}$ and $\mathrm{CH}_{4}$ ages observed in our thermokarst lake and Yedoma meltwater (Fig. 2a). Photo-oxidation can also actively decompose DOC in Arctic inland waters ${ }^{34}$, but is less effective at decomposing ancient Yedoma $\mathrm{C}^{35}$. Our samples were collected in late summer when daylight hours can extend for virtually the whole day, so photo-oxidation was likely an 

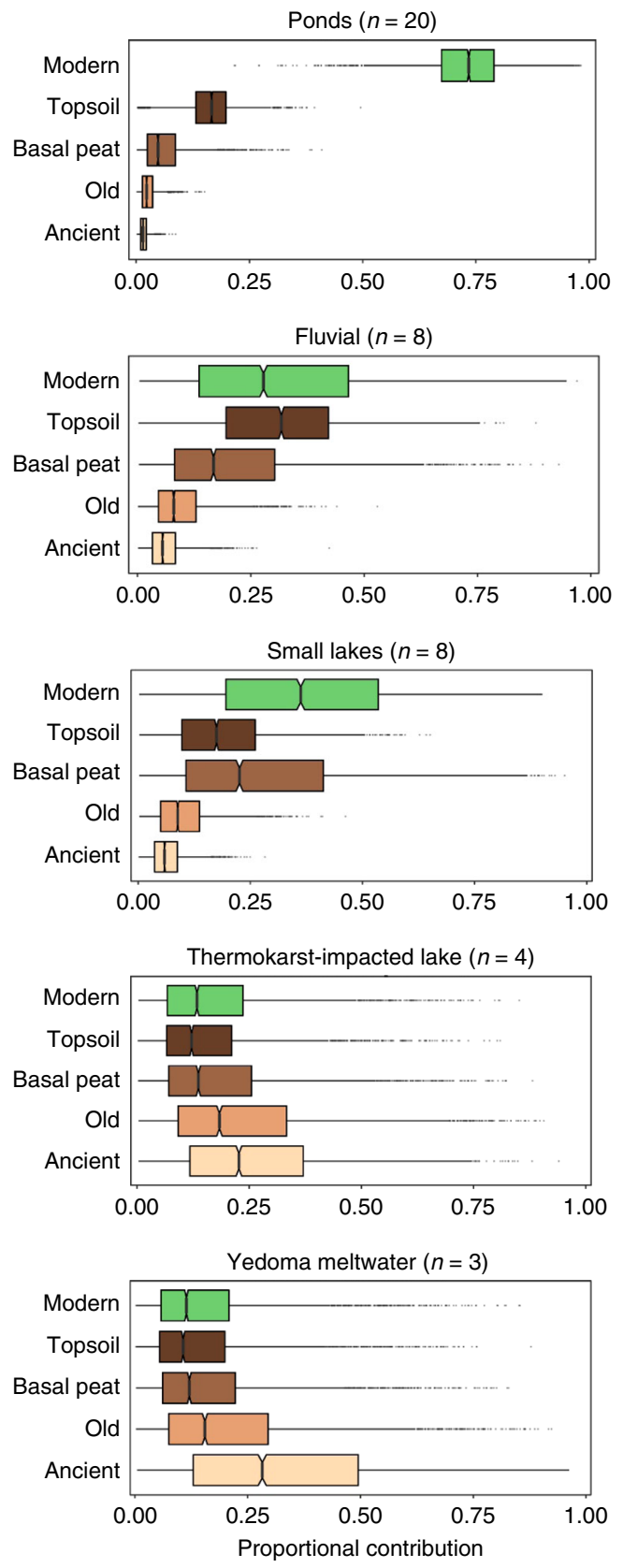

Fig. 3 Relative source contributions to total inland water carbon.

Estimated from a five-source Bayesian isotope mass balance model: modern (2013) atmospheric carbon dioxide $\left(\mathrm{CO}_{2}\right)$; recent, 1950-2012 carbon fixed into plant and soil organic matter in the topsoil; basal peat ages measured at the site representing the oldest carbon available from Holocene peat accumulation (250-1180 yBP)); old carbon in latePleistocene to early Holocene soils (1765-9970 yBP); and ancient Pleistocene-aged Yedoma carbon (>27,920 yBP; Fig. 2a)6,7,22. Notched lines in the boxes represent the median, limits represent upper and lower quartiles, whiskers extend to 1.5 times the interquartile range, dots represent data points beyond this range.

important process of organic $\mathrm{C}$ decomposition. This is supported by the predominance of contemporary $\mathrm{CO}_{2}$ and $\mathrm{CH}_{4}$, indicating that photo-oxidation of contemporary organic $\mathrm{C}$ may be a proportionally more important contributor to inland water emissions in the summer months than microbial decomposition, depending on how much $\mathrm{CO}_{2}$ and $\mathrm{CH}_{4}$ is sourced from organic $\mathrm{C}$ decomposition in the surrounding soils.
Decomposition of pre-aged organic $\mathrm{C}$ has most notably been demonstrated in $\mathrm{CH}_{4}$ ebullition from thermokarst lake sediments that was up to $42,900 \mathrm{yBP}$ in age ${ }^{15}$. In the present study, dissolved $\mathrm{CO}_{2}$ emissions were larger and younger than dissolved $\mathrm{CH}_{4}$, consistent with previously observed Arctic inland water emissions (3-6420 mg C-CO $\mathrm{CO}_{2} \mathrm{~m}^{-2} \mathrm{~d}^{-1}$ versus $1.0-182$ $\left.\mathrm{mgC}-\mathrm{CH}_{4} \mathrm{~m}^{-2} \mathrm{~d}^{-1}\right)^{6,7,36-40}$. Both dissolved $\mathrm{CO}_{2}$ and $\mathrm{CH}_{4}$ emissions were younger and tended to be smaller than $\mathrm{CH}_{4}$ ebullition $\left(0-255 \mathrm{mg} \mathrm{C}-\mathrm{CH}_{4} \mathrm{~m}^{-2} \mathrm{~d}^{-1}\right)^{40}$ which was not measured in our study. $\mathrm{CH}_{4}$ ebullition is usually generated at depth, as opposed to dissolved $\mathrm{CH}_{4}$ which represents a spatiotemporally integrated signal of lake sediment and terrestrial inputs ${ }^{19}$. The generally older age of $\mathrm{CH}_{4}$ ebullition compared with dissolved $\mathrm{CH}_{4}$ indicates that where contemporary organic $\mathrm{C}$ is limited, such as deep unfrozen lake sediments (taliks), pre-aged $\mathrm{C}$ will drive $\mathrm{CH}_{4}$ production ${ }^{15}$. For example, in Alaskan lakes, dissolved $\mathrm{CO}_{2}$ and $\mathrm{CH}_{4}$ collected in winter were older than in summer. This was because frozen lake surfaces prevented inputs of contemporary terrestrial $\mathrm{C}$ and stopped ebullition reaching the surface, which allow these bubbles containing old $\mathrm{CH}_{4}$ and $\mathrm{CO}_{2}$ to dissolve into the water column (refs. ${ }^{6,19}$ ). These age differences further indicate that microbial utilization of pre-aged $\mathrm{C}$ is due to the restricted supply of contemporary organic $\mathrm{C}$, rather than preferential mineralization of pre-aged organic matter.

Inland waters can rapidly turnover contemporary organic $\mathrm{C}^{32,41}$, and the few existing in situ ${ }^{14} \mathrm{C}$ measurements of dissolved $\mathrm{CO}_{2}$ and $\mathrm{CH}_{4}$ across the Arctic have been contemporary in age ${ }^{6,7}$. The export of pre-aged $C$ by inland waters from thawing permafrost landscapes may instead occur as DOC and POC. Our comparison of inland water $\mathrm{CO}_{2}$ and $\mathrm{CH}_{4}$ emissions with the measured terrestrial sink does not account for lateral transport of organic C. With DOC and POC concentrations consistently $c .4$ times higher and generally older than diffuse $\mathrm{CO}_{2}$ and $\mathrm{CH}_{4}$ (Figs. 2 and 4), lateral transport is a potentially important component of landscape $\mathrm{C}$ loss in the region. Mobilized DOC and POC may be transported laterally to lake, fluvial or marine systems where it can be decomposed to $\mathrm{CO}_{2}$ and $\mathrm{CH}_{4}$, or buried in sedimentary reservoirs ${ }^{2,42}$. Rates of lateral transport may be greater at other times of the year than our study period depending on hydrological regimes, e.g., during the Spring snow-melt pulse, and as a result of abrupt thaw events $^{2}$. It is therefore important to track all $\mathrm{C}$ forms across different times of the year to fully capture the export of preaged permafrost $\mathrm{C}$ by inland waters.

Our study region had a slightly lower proportional coverage of inland water bodies compared with a selection of Arctic regions in a recent study: of 31 sites, 29 had higher proportional inland water coverage but only by $4.5 \pm 3.9 \%(\text { mean } \pm 1 \sigma)^{23}$. Inland waters types and their areal coverage in permafrost landscapes could increase or decrease under climate change depending on localized topography and drainage patterns $4,21,23,43$. There is thus a need to capture $\mathrm{C}$ dynamics across a range of water types within the same landscapes, as shown by the variable $\mathrm{C}$ concentrations and isotopic compositions seen across our study sites.

Our observations demonstrate that inland waters in permafrost landscapes are sensitive to both contemporary and pre-aged $\mathrm{C}$ release, although contemporary $\mathrm{C}$ dominates in this landscape. This means that regardless of whether the changing Arctic climate will increase inputs of contemporary or pre-aged $\mathrm{C}$ to inland waters, their annual $\mathrm{CO}_{2}$ and $\mathrm{CH}_{4}$ emissions will likely go up, offsetting terrestrial $\mathrm{C}$ sinks. In the study region, inland water $\mathrm{CO}_{2}$ and $\mathrm{CH}_{4}$ emissions were a small offset of the terrestrial sink $(2.3 \pm 1.5 \%$ in total), so large increases in inland water coverage and supply of terrestrial $\mathrm{C}$ to these waters is needed in order for them to significantly offset the terrestrial sink. 

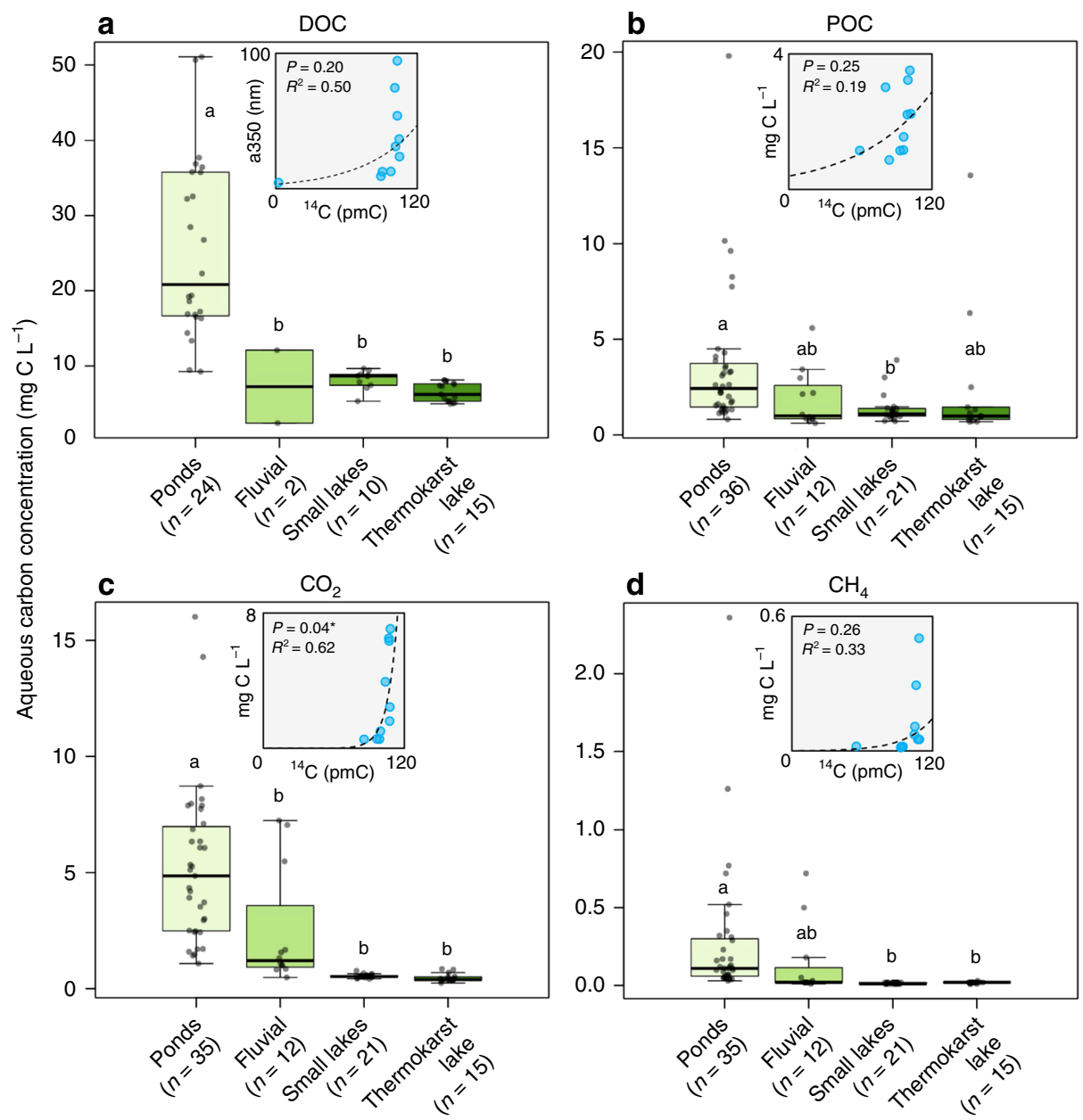

Fig. 4 Concentrations of all carbon forms. a Dissolved organic carbon (DOC), $\mathbf{b}$ particulate organic carbon (POC), $\mathbf{c}$ carbon dioxide $\left(\mathrm{CO}_{2}\right)$, and $\mathbf{d}$ methane $\left(\mathrm{CH}_{4}\right)$ for each sample location; the thick horizontal lines represent the median, limits of the boxes represent upper and lower quartiles, whiskers extend to 1.5 times the interquartile range, dots represent all data points, letters indicate statistical differences between the sample locations using ANOVA (see Methods). Inset: relationship between ${ }^{14} \mathrm{C}$ content and carbon concentrations (absorbance at $350 \mathrm{~nm}$ [a350] for DOC; Supplementary Fig. 4) ${ }^{46}$, excluding Yedoma meltwater (see Methods) (*indicates $P<0.05$ ).

\section{Methods}

Study approach. The study site is in the oligotrophic tundra of the Kytalyk Nature Reserve in the Indigirka River lowlands ${ }^{22}\left(70.83^{\circ} \mathrm{N}, 147.49^{\circ} \mathrm{E}\right.$; Fig. 1). Average active layer depths in the tundra around and beneath the ponds during the study period, July-August, were $26 \pm 12 \mathrm{~cm}$ (mean $\pm 1 \sigma, n=370$; Table S1). The landscape is dominated by a series of drained lake basins formed by thaw driven subsidence and drainage ${ }^{21}$, and the floodplain of the Berelekh River, a major tributary to the Indigirka. A single Yedoma ridge (up to 30-m high) lies within the study region, into which the thermokarst lake is eroding and from which the Yedoma meltwater samples were collected. This ridge is an remnant of organicrich, $\sim 2-6 \%$ C by mass, Pleistocene-aged permafrost sediments deposited as loess or fluvial silts with ice content $30-90 \%$ by volume ${ }^{22}$. The ridge covers $\sim 12 \%$ of the landscape surface and is potentially distributed throughout the region as a result of thaw and erosion ${ }^{22}$ (Fig. 1); such deposits are common throughout northeast Siberia ${ }^{1}$.

The study region is underlain by continuous permafrost limiting potential geological inputs to aquatic $\mathrm{CO}_{2}$ or $\mathrm{CH}_{4}$, and neither ${ }^{14} \mathrm{CO}_{2}$ nor $\delta^{13} \mathrm{C}-\mathrm{CO}_{2}$ (which are in isotopic equilibrium with total dissolved inorganic $\mathrm{C}$ ) correlated with geochemical indicators of rock weathering (e.g., water $\mathrm{Ca}^{2+}$ concentrations). Geological inputs, such as rock weathering ${ }^{47}$ or $\mathrm{CH}_{4}$ seeps ${ }^{48}$, were therefore unlikely to have influenced our observations.

Mean air temperatures during the study period (25 July-17 August 2016) were $10.3 \pm 3.3^{\circ} \mathrm{C}, 7.6 \pm 4.7^{\circ} \mathrm{C}$ during the growing season (June-September 2016), and $-12.4 \pm 16.7^{\circ} \mathrm{C}$ in the year preceding the sampling campaign. These values are within normal temperature ranges for the site (monthly averages range from $9.7^{\circ} \mathrm{C}$ in June to $-34.2^{\circ} \mathrm{C}$ in January) $)^{22}$. Precipitation at the study site occurs mainly as rain during the summer, with an annual mean of $232 \mathrm{~mm}^{22}$; during the sampling period, $30 \mathrm{~mm}$ of rain fell compared with $129 \mathrm{~mm}$ over the 2016 growing season (Supplementary Fig. 1). Vegetation in the tundra areas of the site consists primarily of Eriophorum vaginatum and Eriophorum augustifolium, Betula nana, Carex sp. and Sphagnum sp. The ponds tend to be surrounded by E. vaginatum, E. augustifolium, B. nana, Carex sp., and Sphagnum sp., while the fluvial systems are bordered primarily by Arctophila fulva, Arctagrostis latifolia, and Salix pulchra ${ }^{49}$.

Sampling and analyses. We collected concurrent ${ }^{14} \mathrm{C}, \delta^{13} \mathrm{C}$, and $\mathrm{C}$ concentration samples for DOC, POC, and dissolved $\mathrm{CO}_{2}$ and $\mathrm{CH}_{4}$ from fluvial, pond, small lake and thermokarst lake sites, and Yedoma meltwater. Samples were collected from the edges of water bodies as could be accessed from the shoreline. Multiple C concentration samples were collected from the lake and stream locations to account for spatial variability. Only one location was sampled for ${ }^{14} \mathrm{C}$ and $\delta^{13} \mathrm{C}$ in each of the study lakes due to the prohibitive cost of analyses. However, ${ }^{14} \mathrm{C}$ in dissolved $\mathrm{CO}_{2}$ and $\mathrm{CH}_{4}$ have been shown to be relatively uniform in lakes of equivalent size in Alaska ${ }^{19}$. The stream was sampled in two locations and the five different ponds were sampled for ${ }^{14} \mathrm{C}$ and $\delta^{13} \mathrm{C}$, but again widespread sampling was limited due to cost. Ponds were only sampled once since their small size means that variations in $\mathrm{C}$ source are likely small (Table $\mathrm{S} 1$ ). DOC and POC, and dissolved $\mathrm{CO}_{2}$ and $\mathrm{CH}_{4}$ concentration samples were collected three times from each site during the study period (except Yedoma meltwater, where $n=1$ ) at three-day intervals in daylight hours for consistency. DOM samples were also collected at the same frequency as the concentration samples but only at sites where ${ }^{14} \mathrm{C}$ samples were collected (Fig. 1; except Yedoma meltwater, where $n=1$ ). ${ }^{14} \mathrm{C}$ and $\delta^{13} \mathrm{C}$ samples were collected at a single time point from a selection of these sites between 05 and 09 August 2016 (Fig. 1; Supplementary Data 1) ${ }^{50-54}$; additional $\delta^{13} \mathrm{C}$ samples were 
also collected for $\mathrm{CH}_{4}$ and DOC for quality control ${ }^{55-57}$ (see Supplementary Methods; Supplementary Fig. 8; Supplementary Data 1 and 2).

Isotope mass balance model. The Stable Isotope Mixing Models in R (simmr) package ${ }^{28}$ was used to estimate relative contributions of potential C sources to ${ }^{14} \mathrm{C}$ samples from each group of sample sites (fluvial, pond etc.; Supplementary Table 2). The isotope mass balance model was only used for ${ }^{14} \mathrm{C}$ because $\delta^{13} \mathrm{C}$ is fractionated during $\mathrm{CO}_{2}$ and $\mathrm{CH}_{4}$ production, and so a dual isotope mass balance, common in aquatic organic matter studies ${ }^{58}$, would not work. This approach therefore provides the theoretical possible contributions of different sources following previous studies ${ }^{6,29}$, but here the sources are further constrained by using measured soil organic matter ${ }^{14} \mathrm{C}$ values obtained from the study region ${ }^{22}$. While some water bodies, for example the ponds (see Introduction), are unlikely to receive contributions from pre-aged C sources, we applied the isotope mass balance model with the same end-members to all samples for consistency to demonstrate all possible source contributions that could produce the observed ${ }^{14} \mathrm{C}$ values. We used simmr to carry out a mass balance (Eq. 1), fitting the potential contributions of five different $\mathrm{C}$ sources (see below) using Markov chain Monte Carlo modeling. Ranges and uncertainties in the ${ }^{14} \mathrm{C}$ signature of the different sources were propagated through the model, and model fitting carried out by the Just Another Gibbs Sampler code. Model convergence was only considered acceptable when the upper confidence interval of the final model outputs was $1.00 \pm 0.10$ (ref. ${ }^{28}$ ). We excluded any food web specific functions from the mass balance, such as trophic enrichment factors, or preferential source contributions ${ }^{28}$.

$$
C 14_{\text {group }}=C 14_{\text {modern }}+C 14_{\text {topsoil }}+C 14_{\text {basal peat }}+C 14_{\text {old }}+C 14_{\text {ancient }}
$$

$\mathrm{C} 14_{\text {group }}$ represents the ${ }^{14} \mathrm{C}$ content of the different inland water $\mathrm{C}$ components within each group of sample sites (in pmC; Supplementary Data 1), which is the sum of the mass balance between the proportional contributions of five different $C$ sources; to achieve mass balance, the relative contributions of the five different sources is assumed to sum to 1 . These five sources follow the model used by ref. ${ }^{6}$ but is adapted here to incorporate soil/sedimentary ${ }^{14} \mathrm{C}$ data obtained from the current study site ${ }^{22}$ (Fig. 3). The modern $\mathrm{CO}_{2}$ source $\left(\mathrm{Cl}_{\text {modern }}\right)$ was taken as the most recently available atmospheric ${ }^{14} \mathrm{CO}_{2}$ value: calendar year 2013 from Barrow, Alaska $(103.13 \mathrm{pmC})^{6}$, only 3 -years earlier than the sampling year in the present study. The topsoil source $\left(C 14_{\text {topsoil }}\right)$ represents the uppermost soil C accumulation in the peat soils, reflecting atmospheric ${ }^{14} \mathrm{CO}_{2}$ signatures between 1950 and $2012(123.64 \pm 22.61 \mathrm{pmC}$ [mean \pm $1 \sigma])^{7}$. Basal peat ages $\left(\mathrm{Cl}_{\text {basal peat }}\right)$ represent the oldest $\mathrm{C}$ available from the Holocene peat accumulation layers on top of the Yedoma soils $(91.95 \pm 7.16 \mathrm{pmC})^{22}$. The old C source $\left(\mathrm{Cl}_{\text {old }}\right)$ represents deep layers of early Holocene to late-Pleistocene $\mathrm{C}$ that has come to the surface via cryoturbation $(55.13 \pm 17.19 \mathrm{pmC})^{22}$. Ancient $\mathrm{C}\left(C 14_{\text {ancient }}\right)$ represents Pleistocene-aged Yedoma $\mathrm{C}$ that has been exposed by thermokarst activity and erosion $(3.09 \pm 6.19 \mathrm{pmC})^{22}$.

Inland water $\mathbf{C O}_{\mathbf{2}}$ and $\mathbf{C H}_{\mathbf{4}}$ emissions. Inland water $\mathrm{CO}_{2}$ and $\mathrm{CH}_{4}$ fluxes $(F)$ were calculated using Eq. (2):

$$
F=k \Delta C
$$

where $\Delta C$ is the difference between the observed gas concentration in the water and the expected concentration if the dissolved gas was in equilibrium with the atmosphere, and $k$ is the gas transfer velocity from water to the atmosphere ${ }^{59}$

Atmospheric $\mathrm{CO}_{2}$ and $\mathrm{CH}_{4}$ concentrations were taken from the ambient air samples collected daily during the normal headspace sampling and supplemented with atmospheric concentration data from the eddy covariance tower. Lake $k$ values were calculated using the relationship with wind speed at $10 \mathrm{~m}\left(U_{10}\right.$ in $\left.\mathrm{m} \mathrm{s}^{-1}\right)$ and $k_{600}(k$ normalized to a Schmidt value of 600$)$ from ref. ${ }^{60}:$

$$
k_{600}=2.07+0.215 \cdot U_{10}^{1.7}
$$

$U_{10}$ values were available from the eddy covariance site at 30 min intervals 49 . Pond $k_{600}$ values were taken from ref. ${ }^{61}\left(0.36 \mathrm{~cm} \mathrm{~h}^{-1}\right)$, a low $k_{600}$ value in the context of inland water $k_{600}$ values. Following ref. ${ }^{59}$, for fluvial sites we used the boreal and Arctic stream $k_{600}$ value from ref. ${ }^{62}\left(13.1 \mathrm{~cm} \mathrm{~h}^{-1}\right)$, which is at the lower end of fluvial $k$ values, but at the high end of inland water $k$ values in general. The $k_{600}$ values can then be converted to $k$ :

$$
k=\frac{k_{600}}{\left(\frac{600}{S c}\right)^{-0.5}}
$$

where $S c$ is the Schmidt number in freshwater computed from water temperature ${ }^{59}$.

Tundra $\mathbf{C O}_{\mathbf{2}}$ and $\mathbf{C H}_{\mathbf{4}}$ emissions. Tundra fluxes at the study site were calculated using the eddy covariance method ${ }^{63}$. The eddy covariance tower at the study site (Fig. 1) was installed in 2003 to measure net ecosystem exchange, using an ultrasonic anemometer (Gill Instruments, Lymington, UK, type R3-50) for wind speed and temperature, and water vapor and $\mathrm{CO}_{2}$ concentrations were measured by an openpath infra-red gas analyzer (LI-COR LI-7500, Lincoln, NE, USA) ${ }^{49}$. An open-path infra-red gas analyzer (LI-COR LI-7700) has been used to measure atmospheric $\mathrm{CH}_{4}$ concentrations since 2014. All sensors measure at $10 \mathrm{~Hz}$ and are installed at a height of $4.7 \mathrm{~m}$. Energy balance closure and good co-spectral shapes required for validation of the eddy covariance methods were demonstrated at the site previously ${ }^{44,49}$.
Tundra fluxes were calculated via EddyPro (version 6.2.2) to provide $30 \mathrm{~min}$ mean fluxes. Processing configuration included: 2D rotation of sonic anemometer coordinates, compensation of air density fluctuations (WPL correction), spectroscopic corrections (for LI7700 - $\mathrm{CH}_{4}$ flux only) and spectral corrections. Fluxes of $\mathrm{CO}_{2}$ and $\mathrm{CH}_{4}$ associated with implausible values of gas concentrations, wind speed or sonic temperature caused by frost, precipitation, water condensation on the analyzer lenses or other conditions of sensors disturbance were removed. $\mathrm{CO}_{2}$ fluxes were additionally despiked following standard procedure ${ }^{64}$. Daily fluxes $\left(\mu \mathrm{mol} \mathrm{CO} \mathrm{m}^{-2} \mathrm{~s}^{-1}\right.$ and $\mathrm{nmol} \mathrm{CH}_{4} \mathrm{~m}^{-2} \mathrm{~s}^{-1}$ ) were summed and daily standard deviations propagated (by calculating the square root of the sum of squares of daily $1 \sigma$ uncertainties) for the 23-day study period (25 July-17 August 2016), then converted to a daily C flux $\left(\mathrm{mg} \mathrm{C} \mathrm{m}^{-2} \mathrm{~d}^{-1} \pm 1 \sigma\right.$; Table 1$)$. Values reported in Table 1 are comparable with $\mathrm{CO}_{2}$ fluxes from the same time period in 2003 to 2013, ranging from -1.4 to $-2.3 \mathrm{~g} \mathrm{C} \mathrm{m}^{-2} \mathrm{~d}^{-1}$, and $\mathrm{CH}_{4}$ fluxes from the same time period in 2008 to 2015 (pre-2014 fluxes are from chamber measurements at the site $)^{49}$, ranging from 14.5 to $21.0 \mathrm{~g} \mathrm{C} \mathrm{m}^{-2} \mathrm{~d}^{-1}$. These values are in good agreement with year round fluxes from the site ${ }^{44,49}$ (Supplementary Fig. 1).

Upscaling emissions to the study region. Daily fluxes measured during the 23 -day study period were upscaled to a $15.9-\mathrm{km}^{2}$ study area that encompassed al the study sites (Fig. 1). The area selected for upscaling captures all the landscape to which we know our measurements apply, i.e., all the lakes, ponds and the stream we sampled plus the surrounding tundra, but we did not try and upscale beyond this. The footprint of the eddy covariance tower captures an area of tundra that reflects the majority of land surrounding the sampled inland water locations, and is considered to be representative of the tundra $\mathrm{CO}_{2}$ and $\mathrm{CH}_{4}$ cycling in the immediate region ${ }^{44}$ (Fig. 1). Areal coverage of the fluvial system $\left(0.2 \mathrm{~km}^{2}\right)$, the small lakes $\left(0.2 \mathrm{~km}^{2}\right)$ and the thermokarst lake $\left(0.5 \mathrm{~km}^{2}\right)$ were calculated from Worldview satellite imagery on 15 July 2015 (Fig. 1). Pond coverage was obtained at the study site from satellite imagery and aerial photography from 2002 to 2013 site in a recent study using image classification $(4.9 \pm 0.2 \%$ of the study region) ${ }^{23}$. Daily fluxes of grouped sample locations (fluvial, pond etc.) were multiplied by 23 days and the relative areas of each inland water system to give a total flux to the atmosphere in $\mathrm{Mg} \mathrm{C}$ for the period 25 July-17 August 2016. $1 \sigma$ uncertainties in the flux estimates were propagated through the upscaling by providing maximum and minimum values in the total upscaled fluxes $(x \pm y$ in Table 1). Relative contributions to fluxes from contemporary (atmospheric, topsoil and basal peat $C$ ) versus pre-aged (old and ancient $C$ ) sources were estimated by multiplying the fluxes by the proportional contributions of these sources to the total C load (Supplementary Table 2).

Statistics. Statistics were analyzed in R (version 3.5.1). Linear models were used to analyze correlations between groups, and the strength of relationships assessed using analysis of variance (ANOVA), with post hoc Tukey's honestly significant difference tests (significance level: $p<0.05$ ) carried out using the agricolae package for letters denoting group similarity in, e.g., Fig. 4. Correlations between variables were assessed using Pearson's correlations in the Hmisc package (e.g., p-values in Fig. 4). Yedoma meltwater values were excluded from the correlation with $C$ concentrations in Fig. 4 (insets) because they represent a Yedoma signal that has yet to be released into an inland water system (unlike the thermokarst lake samples), and because there was no Yedoma ${ }^{14} \mathrm{CH}_{4}$ value, nor $\mathrm{CO}_{2}$ or $\mathrm{CH}_{4}$ concentration values, to allow a complete comparison of all correlations.

\section{Data availability}

All data is available in the Supplementary information and Supplementary Data 1 and 2.

Received: 30 October 2019; Accepted: 13 March 2020; Published online: 02 April 2020

\section{References}

1. Strauss, J. et al. Deep Yedoma permafrost: a synthesis of depositional characteristics and carbon vulnerability. Earth-Sci. Rev. 172, 75-86 (2017).

2. Vonk, J. E. et al. Reviews and syntheses: effects of permafrost thaw on Arctic aquatic ecosystems. Biogeosciences 12, 7129-7167 (2015).

3. Box, J. E. et al. Key indicators of Arctic climate change: 1971-2017. Environ Res. Lett. 14, 045010 (2019).

4. Turetsky, M. R. et al. Permafrost collapse is accelerating carbon release. Nature 569, 32-34 (2019)

5. Raymond, P. A. et al. Flux and age of dissolved organic carbon exported to the Arctic Ocean: a carbon isotopic study of the five largest arctic rivers. Glob. Biogeochem. Cycles 21, GB4011 (2007).

6. Elder, C. D. et al. Greenhouse gas emissions from diverse Arctic Alaskan lakes are dominated by young carbon. Nat. Clim. Change 8, 166-171 (2018).

7. Dean, J. F. et al. Abundant pre-industrial carbon detected in Canadian Arctic headwaters: implications for the permafrost carbon feedback. Environ. Res. Lett. 13, 034024 (2018). 
8. Phoenix, G. K. \& Bjerke, J. W. Arctic browning: extreme events and trends reversing arctic greening. Glob. Chang. Biol. 22, 2960-2962 (2016).

9. Xu, L. et al. Temperature and vegetation seasonality diminishment over northern lands. Nat. Clim. Change 3, 581-586 (2013).

10. Schuur, E. A. G. et al. Climate change and the permafrost carbon feedback Nature 520, 171-179 (2015).

11. Dean, J. F. et al. Methane feedbacks to the global climate system in a warmer world. Rev. Geophys. 56, 207-250 (2018).

12. Mann, P. J. et al. Utilization of ancient permafrost carbon in headwaters of Arctic fluvial networks. Nat. Commun. 6, 7856 (2015).

13. Drake, T. W., Wickland, K. P., Spencer, R. G. M., McKnight, D. M. \& Striegl, R. G. Ancient low-molecular-weight organic acids in permafrost fuel rapid carbon dioxide production upon thaw. Proc. Natl Acad. Sci. USA 112, 13946-13951 (2015)

14. Vonk, J. E. et al. High biolability of ancient permafrost carbon upon thaw. Geophys. Res. Lett. 40, 2689-2693 (2013)

15. Walter Anthony, K. et al. Methane emissions proportional to permafrost carbon thawed in Arctic lakes since the 1950s. Nat. Geosci. 9, 679-682 (2016).

16. Cooper, M. D. A. et al. Limited contribution of permafrost carbon to methane release from thawing peatlands. Nat. Clim. Change 7, 507-511 (2017).

17. Estop-Aragonés, C. et al. Limited release of previously-frozen $\mathrm{C}$ and increased new peat formation after thaw in permafrost peatlands. Soil Biol. Biochem. 118, 115-129 (2018).

18. Dyonisius, M. N. et al. Old carbon reservoirs were not important in the deglacial methane budget. Science 367, 907-910 (2020).

19. Elder, C. D. et al. Seasonal sources of whole-lake $\mathrm{CH}_{4}$ and $\mathrm{CO}_{2}$ emissions from interior Alaskan Thermokarst Lakes. J. Geophys. Res. Biogeosciences 124, 1209-1229 (2019).

20. Hicks Pries, C. E., Schuur, E. A. G. \& Crummer, K. G. Thawing permafrost increases old soil and autotrophic respiration in tundra: partitioning ecosystem respiration using $\delta^{13} \mathrm{C}$ and $\Delta^{14} \mathrm{C}$. Glob. Chang. Biol. 19, 649-661 (2013).

21. van Huissteden, J. et al. Methane emissions from permafrost thaw lakes limited by lake drainage. Nat. Clim. Change 1, 119-123 (2011).

22. Weiss, N. et al. Thermokarst dynamics and soil organic matter characteristics controlling initial carbon release from permafrost soils in the Siberian Yedoma region. Sediment. Geol. 340, 38-48 (2016).

23. Muster, S. et al. Size distributions of Arctic waterbodies reveal consistent relations in their statistical moments in space and time. Front. Earth Sci. 7, 5 (2019).

24. Whiticar, M. J. Carbon and hydrogen isotope systematics of bacterial formation and oxidation of methane. Chem. Geol. 161, 291-314 (1999).

25. Marwick, T. R. et al. The age of river-transported carbon: a global perspective. Glob. Biogeochem. Cycles 29, 122-137 (2015).

26. Drake, T. W. et al. The ephemeral signature of permafrost carbon in an Arctic fluvial network. J. Geophys. Res. Biogeosci. 123, 1475-1485 (2018).

27. Evans, C. D. et al. Contrasting vulnerability of drained tropical and highlatitude peatlands to fluvial loss of stored carbon. Glob. Biogeochem. Cycles $\mathbf{2 8}$, 1215-1234 (2014).

28. Parnell, A. C. et al. Bayesian stable isotope mixing models. Environmetrics 24, 387-399 (2013).

29. Waldron, S. et al. C mobilisation in disturbed tropical peat swamps: old DOC can fuel the fluvial efflux of old carbon dioxide, but site recovery can occur. Sci. Rep. 9, 11429 (2019)

30. Lambert, T., Bouillon, S., Darchambeau, F., Massicotte, P. \& Borges, A. V. Shift in the chemical composition of dissolved organic matter in the Congo River network. Biogeosciences 13, 5405-5420 (2016).

31. Cory, R. M. \& Kling, G. W. Interactions between sunlight and microorganisms influence dissolved organic matter degradation along the aquatic continuum. Limnol. Oceanogr. Lett. 3, 102-116 (2018).

32. Campeau, A. et al. Current forest carbon fixation fuels stream $\mathrm{CO}_{2}$ emissions. Nat. Commun. 10, 1876 (2019).

33. Dean, J. F. et al. Biogeochemistry of "pristine" freshwater stream and lake systems in the western Canadian Arctic. Biogeochemistry 130, 191-213 (2016).

34. Cory, R. M., Ward, C. P., Crump, B. C. \& Kling, G. W. Sunlight controls water column processing of carbon in arctic fresh waters. Science 345, 925-928 (2014).

35. Stubbins, A. et al. Low photolability of yedoma permafrost dissolved organic carbon. J. Geophys. Res. Biogeosci. 122, 200-211 (2017)

36. Kling, G. W., Kipphut, G. W. \& Miller, M. C. Arctic lakes and streams as gas conduits to the atmosphere: implications for tundra carbon budgets. Science 251, 298-301 (1991).

37. Crawford, J. T., Striegl, R. G., Wickland, K. P., Dornblaser, M. M. \& Stanley, E. H. Emissions of carbon dioxide and methane from a headwater stream network of interior Alaska. J. Geophys. Res. Biogeosci. 118, 482-494 (2013).

38. Striegl, R. G., Dornblaser, M. M., McDonald, C. P., Rover, J. R. \& Stets, E. G. Carbon dioxide and methane emissions from the Yukon River system. Glob. Biogeochem. Cycles 26, GB0E05 (2012).

39. Bouchard, F. et al. Modern to millennium-old greenhouse gases emitted from ponds and lakes of the Eastern Canadian Arctic (Bylot Island, Nunavut). Biogeosciences 12, 7279-7298 (2015).
40. Wik, M., Varner, R. K., Anthony, K. W., MacIntyre, S. \& Bastviken, D. Climate-sensitive northern lakes and ponds are critical components of methane release. Nat. Geosci. 9, 99-105 (2016).

41. Bogard, M. J. et al. Negligible cycling of terrestrial carbon in many lakes of the arid circumpolar landscape. Nat. Geosci. 12, 180-185 (2019).

42. Hilton, R. G. et al. Erosion of organic carbon in the Arctic as a geological carbon dioxide sink. Nature 524, 84-87 (2015).

43. Liljedahl, A. K. et al. Pan-Arctic ice-wedge degradation in warming permafrost and its influence on tundra hydrology. Nat. Geosci. 9, 312-318 (2016).

44. Parmentier, F. J. W. et al. Spatial and temporal dynamics in eddy covariance observations of methane fluxes at a tundra site in northeastern Siberia. J. Geophys. Res Biogeosciences 116, 1-14 (2011).

45. Schaefer, H. et al. A 21 st-century shift from fossil-fuel to biogenic methane emissions indicated by ${ }^{13} \mathrm{CH}_{4}$. Science 352, 80-84 (2016).

46. Moran, M. A., Sheldon, W. M. \& Zepp, R. G. Carbon loss and optical property changes during long-term photochemical and biological degradation of estuarine dissolved organic matter. Limnol. Oceanogr. 45, 1254-1264 (2000).

47. Billett, M. F., Garnett, M. H. \& Harvey, F. UK peatland streams release old carbon dioxide to the atmosphere and young dissolved organic carbon to rivers. Geophys. Res. Lett. 34, L23401 (2007).

48. Walter Anthony, K. M., Anthony, P., Grosse, G. \& Chanton, J. Geologic methane seeps along boundaries of Arctic permafrost thaw and melting glaciers. Nat. Geosci. 5, 419-426 (2012).

49. Budishchev, A. et al. Evaluation of a plot scale methane emission model at the ecosystem scale using eddy covariance observations and footprint modelling. Biogeosciences 11, 4651-4664 (2014).

50. Garnett, M. H., Billett, M. F. F., Gulliver, P. \& Dean, J. F. A new field approach for the collection of samples for aquatic ${ }^{14} \mathrm{CO}_{2}$ analysis using headspace equilibration and molecular sieve traps: the super headspace method. Ecohydrology 9, 1630-1638 (2016).

51. Dean, J. F., Billett, M. F., Murray, C. \& Garnett, M. H. Ancient dissolved methane in inland waters revealed by a new collection method at low field concentrations for radiocarbon $\left({ }^{14} \mathrm{C}\right)$ analysis. Water Res. 115, 236-244 (2017).

52. Gulliver, P., Waldron, S., Scott, E. M. \& Bryant, C. L. The effect of storage on the radiocarbon, stable carbon and nitrogen isotopic signatures and concentrations of riverine DOM. Radiocarbon 52, 1113-1122 (2010).

53. $\mathrm{Xu}$, S. et al. Capabilities of the new SUERC $5 \mathrm{MV}$ AMS facility for ${ }^{14} \mathrm{C}$ dating. Radiocarbon 46, 59-64 (2004)

54. Stuiver, M. \& Polach, H. A. Discussion reporting of ${ }^{14} \mathrm{C}$ data. Radiocarbon 19, 355-363 (1977).

55. Brass, M. \& Röckmann, T. Continuous-flow isotope ratio mass spectrometry method for carbon and hydrogen isotope measurements on atmospheric methane. Atmos. Meas. Tech. 3, 1707-1721 (2010).

56. St-Jean, G. Automated quantitative and isotopic $\left({ }^{13} \mathrm{C}\right)$ analysis of dissolved inorganic carbon and dissolved organic carbon in continuous-flow using a total organic carbon analyser. Rapid Commun. Mass Spectrom. 17, 419-428 (2003).

57. Bouillon, S., Korntheuer, M., Baeyens, W. \& Dehairs, F. A new automated setup for stable isotope analysis of dissolved organic carbon. Limnol. Oceanogr. Methods 4, 216-226 (2006).

58. Bröder, L., Tesi, T., Andersson, A., Semiletov, I. \& Gustafsson, Ö. Bounding cross-shelf transport time and degradation in Siberian-Arctic land-ocean carbon transfer. Nat. Commun. 9, 806 (2018)

59. Borges, A. V. et al. Globally significant greenhouse-gas emissions from African inland waters. Nat. Geosci. 8, 637-642 (2015)

60. Cole, J. J. \& Caraco, N. F. Atmospheric exchange of carbon dioxide in a lowwind oligotrophic lake measured by the addition of SF 6. Limnol. Oceanogr. 43, 647-656 (1998)

61. Holgerson, M. A. \& Raymond, P. A. Large contribution to inland water $\mathrm{CO}_{2}$ and $\mathrm{CH}_{4}$ emissions from very small ponds. Nat. Geosci. 9, 222-226 (2016).

62. Aufdenkampe, A. K. et al. Riverine coupling of biogeochemical cycles between land, oceans, and atmosphere. Front. Ecol. Environ. 9, 53-60 (2011).

63. Aubinet, M. et al. Estimates of the annual net carbon and water exchange of forests: the EUROFLUX methodology. Adv. Ecol. Res. 30, 113-175 (1999).

64. Papale, D. et al. Towards a standardized processing of Net Ecosystem Exchange measured with eddy covariance technique: algorithms and uncertainty estimation. Biogeosciences 3, 571-583 (2006)

\section{Acknowledgements}

This work was carried out under the program of the Netherlands Earth System Science Centre (NESSC), financially supported by the Ministry of Education, Culture and Science (OCW), grant number: 024.002.001. L.B.M. acknowledges the support of the RUDN University program 5-100. A.V.B. is a senior research associate at the Fonds National de la Recherche Scientifique (FNRS). We thank Caitlyn Witkowski of the University of Bristol for comments on draft versions of the paper. 


\section{Author contributions}

J.F.D., T.M., R.A., J.v.H. and A.J.D. conceived the study and contributed to general logistics. J.F.D., O.H.M., L.B.M., H.L., R.v.L., R.P., S.K., J.v.H. and A.J.D. contributed to fieldwork and logistics. J.F.D., M.M.R., L.B.M., M.H.G., H.L., R.v.L., A.V.B., S.B., T.L.,

T.R. and J.E.V. contributed to lab work, sample analyses and data analyses. J.F.D. wrote the paper; all authors contributed to draft versions prior to submission.

\section{Competing interests}

The authors declare no competing interests.

\section{Additional information}

Supplementary information is available for this paper at https://doi.org/10.1038/s41467020-15511-6.

Correspondence and requests for materials should be addressed to J.F.D.

Peer review information Nature Communications thanks Clayton Elder, and the other, anonymous, reviewer(s) for their contribution to the peer review of this work. Peer reviewer reports are available.
Reprints and permission information is available at http://www.nature.com/reprints

Publisher's note Springer Nature remains neutral with regard to jurisdictional claims in published maps and institutional affiliations.

(c) Open Access This article is licensed under a Creative Commons Attribution 4.0 International License, which permits use, sharing, adaptation, distribution and reproduction in any medium or format, as long as you give appropriate credit to the original author(s) and the source, provide a link to the Creative Commons license, and indicate if changes were made. The images or other third party material in this article are included in the article's Creative Commons license, unless indicated otherwise in a credit line to the material. If material is not included in the article's Creative Commons license and your intended use is not permitted by statutory regulation or exceeds the permitted use, you will need to obtain permission directly from the copyright holder. To view a copy of this license, visit http://creativecommons.org/ licenses/by/4.0/.

(C) The Author(s) 2020 